\title{
Germination and vigor of seeds of Magonia pubescens A. St.-Hil. submitted to storage and pre-imbibition in water $^{1}$
}

\author{
Cárita Rodrigues de Aquino Arantes², Carmen Lúcia Ferreira Fava ${ }^{3}$, \\ Elisangela Clarete Camili ${ }^{3}$, Walcylene Lacerda Matos Pereira Scaramuzza ${ }^{4}$
}

\begin{abstract}
Timbó (Magonia pubescens A. St.-Hil.) is a species with ornamental potential, which can be used in composition of gardens, squares and especially in streets landscaping. It is also suitable for planting in degraded areas of permanent preservation. This work aimed to verify the effect of seed size, storage and pre-imbibition time on seed germination and vigor. The test design was completely randomized, in a plot scheme subdivided in time. The main plots were seed size (large and small), packaging $(0.5 \mathrm{~mm}$-thick transparent polyethylene and kraft paper bag), and time of imbibition in water ( 0,12 and 24 hours); and as subplots, it was considerate the storage times $(0,3,6,9$ and 12 months). The tests were carried out in five replications of ten seeds, and the evaluated variables were: water content of the seeds, percentage of germination ( $\% \mathrm{G})$, mean germination time (MGT), shoot height (cm), collar diameter (mm), number of leaves, and fresh and dry mass of the aerial part (g). The size of the seed did not influence the germination percentage, but large seeds formed more vigorous seedlings. The storage did not affect seeds germination, nor the vigor of the seedlings. Seed preimbibition did not influence the percentage of germination, but the mean germination time decreased, and more vigorous seedlings were formed. In order to obtain more vigorous Timbó seedlings, the best option is to use large seeds. They can be stored for up to 12 months without losing vigor and pre-soaked to accelerate the beginning of germination, thus forming a more homogeneous lot of seedlings.
\end{abstract}

Index terms: timbó, Sapindaceae, native plant, seed storage.

\section{Germinação e vigor de sementes de Magonia pubescens A. St.-Hil. submetidas ao armazenamento e pré-embebição em água}

\begin{abstract}
RESUMO - O timbó (Magonia pubescens A. St.-Hil.) é uma espécie com potencial ornamental, podendo ser usado na composição de jardins e praças e, principalmente, para arborização de ruas; é ainda indicado para plantios em áreas degradadas de preservação permanente. O objetivo neste trabalho foi verificar o efeito do tamanho das sementes, do armazenamento e do tempo de pré-embebição das sementes na sua germinação e vigor. O delineamento utilizado foi inteiramente casualizado, em parcela subdividida no tempo, sendo alocados na parcela principal: tamanho da semente (grandes e pequenas), embalagem (polietileno transparente com espessura de $0,5 \mathrm{~mm}$ e saco de papel kraft) e tempo de embebição em água ( 0,12 e 24 horas); e nas subparcelas o tempo de armazenamento (0, 3, 6, 9 e 12 meses), com cinco repetições de dez sementes. As características avaliadas foram o teor de água das sementes, a porcentagem de germinação $(\% \mathrm{G})$, o tempo médio de germinação (TMG), a altura da parte aérea (cm), o diâmetro do colo (mm), o número de folhas e as massas fresca e seca da parte aérea $(\mathrm{g})$. O tamanho da semente não influenciou na porcentagem de germinação, porém, as sementes grandes formaram plântulas mais vigorosas. O armazenamento não prejudicou a germinação das sementes, nem mesmo o vigor das plântulas. A pré-embebição das sementes não influenciou na porcentagem de germinação, no entanto, diminuiu o tempo médio de germinação, formando plântulas mais vigorosas. Para se conseguir plântulas de timbó mais vigorosas sementes grandes são a melhor opção, podendo ser armazenadas por até 12 meses sem perda de vigor e pré-embebidas para acelerar o início da germinação, formando um lote de plântulas mais homogêneo.
\end{abstract}

Termos para indexação: timbó, Sapindaceae, planta nativa, armazenamento de sementes.

${ }^{1}$ Submitted on 10/11/2016. Accepted for publication on $09 / 29 / 2017$.

${ }^{2}$ Universidade Federal de Mato Grosso, 78060-900 - Cuiabá, MT, Brasil.

${ }^{3}$ Departamento de Fitotecnia e Fitossanidade, Universidade Federal de Mato Grosso, 78060-900 - Cuiabá, MT, Brasil.
${ }^{4}$ Departamento de Solos e Engenharia Rural, Universidade Federal de Mato Grosso, 78060-900 - Cuiabá, MT, Brasil.

*Corresponding author <carita.rodrigues@hotmail.com> 


\section{Introduction}

The original vegetation of the Brazilian Cerrado has many species of interest, such as fruit trees, medicinal plants, timber and ornamental plants. Among these species, it is timbó or tingui (Magonia pubescens A. St.-Hil., Sapindaceae), used in different ways by traditional populations. Timbó is a deciduous, heliophyte and selective-xerophyte tree, which occurs naturally and it is widely distributed in the Cerrados of Central Brazil. It can be found in the states of Ceará, Goiás, Mato Grosso, Mato Grosso do Sul, Minas Gerais and São Paulo (Lorenzi, 2009).

The tree has ornamental potential, especially for its lacy foliage, and can be used in composition of gardens, squares and for streets landscaping. It is also indicated for planting in degraded permanent preservation areas (Giotto et al., 2009; Lorenzi, 2009). It has moderate dense $\left(600 \mathrm{~kg} . \mathrm{m}^{-3}\right)$, hard, medium-textured wood, with good resistance to xylophagous organisms attack. It can also be used in civil construction, as rafters, slats, door and window frames, as fencepost, firewood and charcoal.

Root bark infusion is used to tinguijar (intoxicate) fishes in lagoons to ease their capture (Lorenzi, 2009). Stem bark ethanolic extract of $M$. pubescens has a potential in controlling Aedes aegypti larvae (Arruda et al., 2003; Silva et al., 2003). Since it is a species exploited by extractivism in natural populations, it is necessary to investigate propagation techniques as a viable way of conservation and reproduction of this species, thus contributing to minimize biodiversity loss.

Seed production of native species is cyclical and characterized by one year of high yield, followed by one or two years of low yield. Besides, seeds generally are not used right after being collected, thus they should be stored for further use in the same year or even in following years (Benedito et al., 2011). Therefore, after being harvested and until their use, seeds should be stored in such a way as to delay the deterioration process as much as possible (Grunennvaldt et al., 2014).

The type of packaging affects seed viability of many species in distinct ways. Ferreira et al. (2010) studied different storage conditions of pau-de-jangada seeds (Apeiba tibourbou Aubl.) with $7.62 \%$ initial water content. After 180 days in laboratory natural environment, with a temperature of up to $28{ }^{\circ} \mathrm{C}$ and relative humidity of up to $82.5 \%$, they found out that the most suitable condition to preserve seeds with little vigor loss was in polyethylene bags. For xique-xique seeds (Pilosocereus gounellei (A. Weber ex K. Schum.) Bly. Ex Rowl.) with initial water content ranging from 7 to $12 \%$, permeable package (multilayered paper bag) was the ideal storage condition to maintain seed viability for 180 days, in laboratory natural environment at $26.6{ }^{\circ} \mathrm{C}$ and $76.9 \%$ relative humidity (Abud et al., 2012).
Seeds classification by size or mass is a strategy to standardize the emergence of seedlings and to obtain seedlings of similar size or of greater vigor, presuming that larger seeds were better nourished during development and consequently are more vigorous (Carvalho and Nakagawa, 2012).

One of the procedures that can be used to maximize and standardize seed germination is pre-imbibition in water, which turns on the metabolism. Macedo et al. (2009) found out that pre-soaking M. pubescens seeds in water for 24 hours provided a greater germination and produced more vigorous seedlings. However, they did not evaluate different times of pre-imbibition in water.

These results suggest that seeds of $M$. pubescens require hydration before sowing in order to maximize germination and, consequently, the amount of seedlings obtained. However, the best duration for this pre-imbibition is unknown. Seed size can also influence the imbibition; Souza et al. (1996) found that smaller seeds of Calopogonium mucunoides absorbed water faster than the larger ones.

Thus, this work aimed to verify the effect of seed size, storage and pre-imbibition time on germination and vigor of seeds of M. pubescens.

\section{Material and Methods}

Timbó seeds were obtained from ripe fruits, harvested from trees located in the region of the Chapada dos GuimarãesMT (15'31'14 ''S, 56 04'17'”), $217 \mathrm{~m}$ above sea level. The collection was realized with pruning shears, in August and September, 2013.

Based on biometric analyzes of the seed lot, a minimum and a maximum limits were established to separate small and large seeds, according to size predominance. Seeds with dimensions ranging from 35 to $50 \mathrm{~mm}$ in length, and from 64 to $93 \mathrm{~mm}$ in width were considered small, while seeds with dimensions of 51 to $63 \mathrm{~mm}$ long and 94 to $108 \mathrm{~mm}$ wide were considered large.

The treatments took into account seed size (large and small); packaging $\left(0.5 \mathrm{~mm}\right.$-thick clear polyethylene and $40 \mathrm{~g} . \mathrm{m}^{2} \mathrm{kraft}$ paper); and imbibition time in enough water to cover the seeds $(0$, 12 and 24 hours). They were carried out in storage time subplots $(0,3,6,9$ and 12 months), with five replications of ten seeds each. Seeds were stored with ala, in their respective packages, inside refrigerated room at $18 \pm 2{ }^{\circ} \mathrm{C}$ and relative humidity of 63 $\pm 4 \%$. The experimental design was completely randomized, in a plot scheme subdivided in time.

The treatments were evaluated before and after each storage time, according to seed water content, percentage of germination ( $\% \mathrm{G})$, mean germination time (MGT), shoot 
height $(\mathrm{cm})$, collar diameter $(\mathrm{mm})$, number of leaves, shoot fresh mass (g) and shoot dry mass (g).

Water content of the seeds was determined initially and after each storage and pre-imbibition period, based on Rules for Seed Testing (Brasil, 2009). Therefore, seeds were kept in an oven at $105 \pm 3{ }^{\circ} \mathrm{C}$ for 24 hours. Ten replications of one seed without ala were done for each treatment (seed size, imbibition time and packaging).

Despite being kept during storage, the ala was cut off with scissors before the immersion in water. Pre-soaking was performed after each storage period and, right after that, the seeds were put to germinate in plastic boxes of $20 \times 30 \times 9 \mathrm{~cm}$ dimension. The substrate used was a mixture of sand and fine expanded vermiculite in a ratio of $1: 1$. The sand was oven sterilized at $105^{\circ} \mathrm{C}$ for eight hours. The substrate was watered to the equivalent of $60 \%$ of its retention capacity (Brasil, 2009), and the treatments were watered twice, in order to replenish their moisture.

The evaluations to establish the percentage of germination and mean germination time, and percentage and mean formation time of normal seedlings were performed according to Maguire (1962), on a daily basis, for 30 days from sowing. Seeds were considered germinated when a $2 \mathrm{~mm}$-length epicotyl was observed, and it was considered seedlings those that presented a well developed shoot, containing two definitive leaves.

At the end of the observation period, seedlings height was measured from the collar region to the last leaf insertion point, and the results were expressed in $\mathrm{cm}^{\text {.seedling }}{ }^{-1}$. The collar diameter $\left(\mathrm{mm}\right.$. seedling $\left.^{-1}\right)$ at the substrate level, the total number of leaves in each seedling and the fresh and dry mass of the shoot (g.seedling ${ }^{-1}$ ) were also evaluated.

To determine the fresh mass of the shoot, the material was weighed in a scale, to four decimal places precision. The dry mass was obtained by weighting the material after drying in a forced air circulation oven at $80{ }^{\circ} \mathrm{C}$ for $24 \mathrm{~h}$, and packed in paper bags (Brasil, 2009).

The data were submitted to analysis of variance. When there was significance, means were compared by the Scott-Knott test $(\mathrm{p}<0.05)$, using SISVAR 5.3 software (Ferreira, 2010).

\section{Results and Discussion}

The initial water content of the seeds of M. pubescens was 6.98 and $5.91 \%$ for small and large seeds, respectively (Table 1). Coelho et al. (2012) verified that the initial water content of M. pubescens seeds was $6.39 \%$, value within the variation range observed in this work. However, according to Souza Filho et al. (2011), the initial water content of $M$. pubescens seeds was $10.8 \%$ and, when they were stored in polyethylene bags and inside climate-controlled room at $18{ }^{\circ} \mathrm{C}$ for 70 days, this value reduced to $10.3 \%$. After 173 days of storage, the water content of seeds decreased to $9.9 \%$.

Seeds size affected water content after six and nine months of storage, in cases that they had been packed in polyethylene bag and had been submitted to 12 or 24 hours of pre-soaking. It also influenced the water content after 12 months of storage, in cases that they had been packed in paper bag and had undergone 12 hours of pre-imbibition. In all situations, the water content of large seeds was bigger than that of small seeds (Table 1).

Pre-imbibition increased seeds water content considerably, independently of how long they had remained in soaking ( 12 or 24 hours). However, differences in the water content of pre-soaked seeds were observed only when they were initially evaluated, i.e., before being stored, regardless of their size. Also, in the small seeds stored for three and nine months in paper bag, in the large seeds stored for nine months in polyethylene bag, and in the large ones stored for 12 months in polyethylene bag, the water content of seeds that had pre-soaked for 24 hours was higher (Table 1).

The type of packaging influenced the water content of seeds only after six, nine and twelve months of storage. At these three evaluation times, the average water content of seeds stored in polyethylene bags was higher than that of seeds kept in paper bags (Table 1). Matos et al. (2008) verified that the packaging influenced the water content of Apeiba tibourbou seeds only after 90 days of storage, and that seeds stored in polyethylene bags had water content lower than those stored in paper bags, regardless of the environment.

Seed size and pre-imbibition time did not influence the final percentage of germination of non-stored seeds (Table 2). On the other hand, seeds that had pre-soaked for 12 or 24 hours, regardless of their size, had their mean germination time (MGT) reduced by almost a half, in relation to non-pre-soaked seeds (Table 2). This occurred because the seeds submitted to preimbibition were already in an advanced process of germination, in comparison to those that were not pre-soaked before sowing.

Araújo et al. (2009) obtained higher percentage of germination and germination speed, as well as a faster stabilization of the process, in seeds of early dwarf-cashew clones that had pre-soaked in water for 24 hours. The advantage of seed pre-imbibition is that it accelerates the germination process by reducing the time seeds are exposed to environmental conditions before germinating. This reduces the possibility of contact with pathogens existing in the substrates, which can deteriorate seeds and reduce their viability.

In many species, the size of the seed is an indication of its physiological quality, and small seeds often present lower germination and vigor than medium and large ones (Popinigis, 
Table 1. Water content (\%) of small and large seeds of Magonia pubescens at the beginning and after each soaking and storage period.

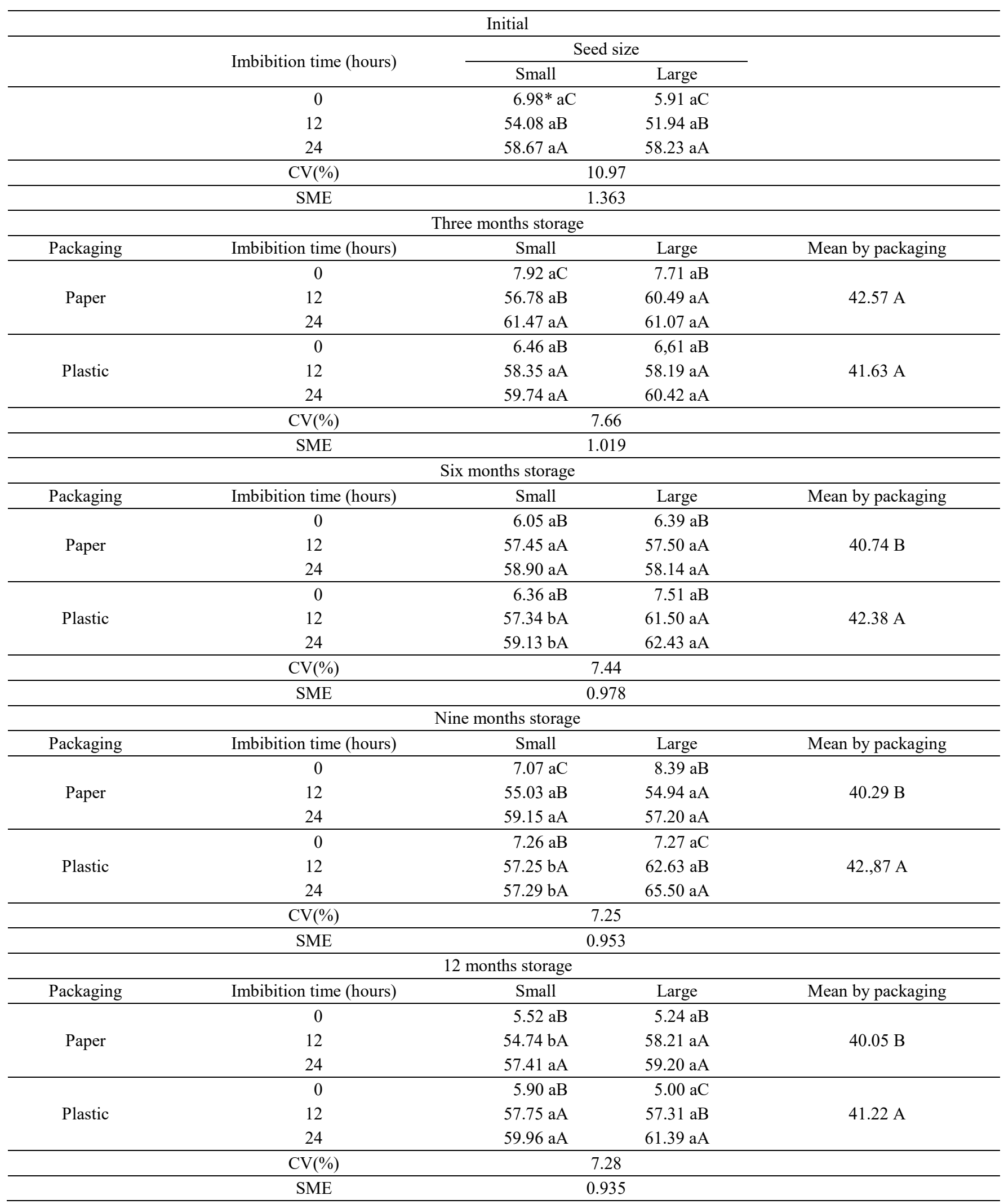

* Means followed by the same lowercase letter in the row within each package for each imbibition time, and means followed by the same uppercase letter in the column within each size and package do not differ statistically from one another by the Scott-Knott test $(\mathrm{p}<0.05)$. SME: Standard Mean Error. 
Table 2. Percentage of germination (\%) and mean germination time (MGT / days) of small and large seeds of Magonia pubescens submitted to different imbibition times before storage.

\begin{tabular}{|c|c|c|c|c|}
\hline & \multirow{2}{*}{$\begin{array}{c}\text { Imbibition time } \\
\text { (hours) }\end{array}$} & \multicolumn{2}{|c|}{ Seed size } & \multirow{2}{*}{ Mean } \\
\hline & & Small & Large & \\
\hline \multirow{6}{*}{$\begin{array}{c}\text { Germination } \\
(\%)\end{array}$} & 0 & $92 \mathrm{aA}^{*}$ & $92 \mathrm{aA}$ & $92 \mathrm{~A}$ \\
\hline & 12 & $96 \mathrm{aA}$ & $94 \mathrm{aA}$ & $95 \mathrm{~A}$ \\
\hline & 24 & $98 \mathrm{aA}$ & $98 \mathrm{aA}$ & $98 \mathrm{~A}$ \\
\hline & Mean & $95 \mathrm{a}$ & $95 \mathrm{a}$ & \\
\hline & CV (\%) & & 7.92 & \\
\hline & SME & & 0.337 & \\
\hline \multirow{6}{*}{$\begin{array}{l}\text { MGT } \\
\text { (days) }\end{array}$} & 0 & $14.4 \mathrm{aB}$ & $15.9 \mathrm{aB}$ & $15.1 \mathrm{~B}$ \\
\hline & 12 & $7.8 \mathrm{aA}$ & $9.3 \mathrm{aA}$ & $8.5 \mathrm{~A}$ \\
\hline & 24 & $7.4 \mathrm{aA}$ & $9.3 \mathrm{aA}$ & $8.3 \mathrm{~A}$ \\
\hline & Mean & $9.9 \mathrm{a}$ & $11.5 \mathrm{~b}$ & \\
\hline & CV (\%) & & 16.69 & \\
\hline & SME & & 0.797 & \\
\hline
\end{tabular}

* Means followed by the same lowercase letters in the row and the same capital letter in the column do not differ statistically from one another by the Scott-Knott test $(\mathrm{p}<0.05)$. SME: Standard Mean Error.

1985). However, in this work, seed size did not affect the percentage of germination, although the MGT of large seeds was longer than the average value (Table 2).

The size of the seeds did not influence the percentage of germination of the stored ones. On the other hand, seed pre-imbibition, regardless of the duration (12 or 24 hours), influenced the germination percentage on both small and large seeds, stored for three and six months in polyethylene bag. It also affected large seeds stored for the same period in paper bag, and both small and large seeds stored for 12 months in polyethylene bag (Table 3 ).

The percentage of germination in the first storage period was $84 \%$, regardless of packaging and seed size. However, after six, nine and 12 months of storage, there was an increase in this percentage (Table 3). According to Scalon et al. (2006), this reduction in the percentage of germination in early storage may occur due to some adaptation mechanism to the new environmental condition to which the seeds are submitted.

Similar result was obtained by Matos et al. (2008) for seeds of A. tibourbou. They verified that seeds kept in kraft paper bags and in polyethylene bags, and then stored in a laboratory environment, presented a reduction in the percentage of germination after 45 days of storage. However, from 90 days on, the percentage of germination increased gradually during the 225 days of storage.

Packaging only influenced the percentage of germination after 12 months of storage; in which case, seeds kept in paper bag had a higher percentage of germination than those stored in polyethylene bag (Table 3). In comparison to other species, Matos et al. (2008) observed that seeds of Apeiba tibourbou with initial water content of $7.62 \%$ maintained their percentage of germination when stored either in kraft paper or polyethylene bag. Batista et al. (2011) verified the same effect in Cedrela odorata seeds stored with $39.7 \%$ water content. In such a condition, both seeds stored in polyethylene bag and the ones kept in kraft paper bags maintained their germination, without showing differences between the package types.

Seed size only influenced the MGT of seeds stored for three months, in both packaging. It also affected seeds stored for six months inside paper bag, and those stored for nine months in polyethylene bag. In all cases, the MGT of small seeds was shorter than that of large seeds. The preimbibition of the seeds, regardless of the duration (12 or 24 hours), significantly reduced the MGT (Table 3 ). This agrees with the result obtained by Araújo et al. (2009), who verified that pre-soaking Anacardium occidentale seeds in water had accelerated the process of germination.

Regarding the characteristics of seedlings produced from non-stored seeds, it was observed that seed size did not affect the height of the seedlings. On the other hand, pre-imbibition only influenced the height of seedlings produced from large seeds, and those from seeds that pre-imbibed for 24 hours were bigger than the others (Table 4). This happened because the seeds that had pre-imbibed for 24 hours germinated faster and consequently formed seedlings first.

Pre-imbibition did not influence the collar diameter of seedlings. Regarding seed size, large seeds that hadn't been pre-soaked formed seedlings with larger collar diameter than the small seeds did (Table 4). According to Carvalho and Nakagawa (2012), larger seeds generally are better nourished during development, so they have well-formed embryos and a larger amount of reserve substances, thus being more vigorous. As stated by Haig and Westoby (1991), the larger the amount of reserve substances in seeds, the higher the possibility of success in establishing the seedling, since this reserves make the survival possible for a longer time in environmental conditions which neither the usage of nutrients and water from the soil nor the photosynthesis are possible yet.

Seed size did not influence the number of leaves. However, as the pre-imbibition time increased, a greater number of leaves was observed (Table 4). Seed size influenced the fresh mass of the seedlings shoot only when seeds had been presoaked for 12 hours. In this case, large seeds formed seedlings with more fresh mass accumulation. The results for dry mass of the shoot followed the same pattern, and differences were observed only in seeds that had pre-soaked for 12 hours. In this case, large seeds formed seedlings with greater amount of dry mass (Table 4). 
Table 3. Percentage of germination (\%) and mean germination time (MGT/ days) of small and large seeds of Magonia pubescens submitted to different imbibition times, after storage in different packages.

\begin{tabular}{|c|c|c|c|c|c|c|c|}
\hline \multicolumn{8}{|c|}{ Germination (\%) } \\
\hline \multirow{2}{*}{$\begin{array}{l}\text { Storage time } \\
\text { (months) }\end{array}$} & \multirow{2}{*}{ Packaging } & \multirow{2}{*}{ Seed size } & \multicolumn{3}{|c|}{ Imbibition time (hours) } & \multirow{2}{*}{$\begin{array}{l}\text { Mean by } \\
\text { storage }\end{array}$} & \multirow{2}{*}{$\begin{array}{l}\text { Mean by } \\
\text { packaging }\end{array}$} \\
\hline & & & 0 & 12 & 24 & & \\
\hline \multirow{4}{*}{3} & \multirow{2}{*}{ Polyethylene } & Small & $76^{*} \mathrm{bA}$ & $96 \mathrm{aA}$ & $94 \mathrm{aA}$ & \multirow{4}{*}{$84 \mathrm{~B}$} & \\
\hline & & Large & $68 \mathrm{bA}$ & $90 \mathrm{aA}$ & $88 \mathrm{aA}$ & & $85 \mathrm{~A}$ \\
\hline & \multirow{2}{*}{ Paper } & Small & $84 \mathrm{aA}$ & $76 \mathrm{aA}$ & $80 \mathrm{aA}$ & & \multirow{2}{*}{$82 \mathrm{~A}$} \\
\hline & & Large & $72 \mathrm{bA}$ & $84 \mathrm{aA}$ & $94 \mathrm{aA}$ & & \\
\hline \multirow{4}{*}{6} & \multirow{2}{*}{ Polyethylene } & Small & $82 \mathrm{bA}$ & $100 \mathrm{aA}$ & $98 \mathrm{aA}$ & & \multirow{2}{*}{$93 \mathrm{~A}$} \\
\hline & & Large & $78 \mathrm{bA}$ & $98 \mathrm{aA}$ & $100 \mathrm{aA}$ & & \\
\hline & \multirow{2}{*}{ Paper } & Small & $92 \mathrm{aA}$ & $100 \mathrm{aA}$ & $100 \mathrm{aA}$ & $93 \mathrm{~A}$ & \multirow{2}{*}{$94 \mathrm{~A}$} \\
\hline & & Large & $80 \mathrm{bA}$ & $94 \mathrm{aA}$ & $100 \mathrm{aA}$ & & \\
\hline \multirow{4}{*}{9} & \multirow{2}{*}{ Polyethylene } & Small & $92 \mathrm{aA}$ & $100 \mathrm{aA}$ & $100 \mathrm{aA}$ & & \multirow{2}{*}{$95 \mathrm{~A}$} \\
\hline & & Large & $86 \mathrm{aA}$ & $94 \mathrm{aA}$ & $96 \mathrm{aA}$ & & \\
\hline & & Small & $96 \mathrm{aA}$ & $100 \mathrm{aA}$ & $100 \mathrm{aA}$ & $96 \mathrm{~A}$ & \multirow{2}{*}{$98 \mathrm{~A}$} \\
\hline & & Large & $96 \mathrm{aA}$ & $96 \mathrm{aA}$ & $98 \mathrm{aA}$ & & \\
\hline \multirow{6}{*}{12} & \multirow{2}{*}{ Polyethylene } & Small & $72 \mathrm{bA}$ & $100 \mathrm{aA}$ & $100 \mathrm{aA}$ & & \\
\hline & & Large & $74 \mathrm{bA}$ & $100 \mathrm{aA}$ & $98 \mathrm{aA}$ & & $91 \mathrm{~B}$ \\
\hline & Paner & Small & $98 \mathrm{aA}$ & $100 \mathrm{aA}$ & $100 \mathrm{aA}$ & $94 \mathrm{~A}$ & $97 \mathrm{~A}$ \\
\hline & Paper & Large & $88 \mathrm{aA}$ & $96 \mathrm{aA}$ & $100 \mathrm{aA}$ & & $97 \mathrm{~A}$ \\
\hline & & $\mathrm{CV}(\%)$ & & & 12.02 & & \\
\hline & & SME & & 4.932 & & 1.424 & 2.013 \\
\hline & & & IGT (days) & & & & \\
\hline Storage time & & Sood cino & & tion time & & Mean by & Mean by \\
\hline (months) & Packaging & Seed size & 0 & 12 & 24 & storage & packaging \\
\hline & & Small & $14.0 \mathrm{bA}$ & $7.8 \mathrm{aA}$ & $9.0 \mathrm{aA}$ & & \\
\hline & Polyethylene & Large & $19.1 \mathrm{bB}$ & $7.3 \mathrm{aA}$ & $7.8 \mathrm{aA}$ & & $10.8 \mathrm{~A}$ \\
\hline 3 & Paner & Small & $15.3 \mathrm{bA}$ & $8.5 \mathrm{aA}$ & $7.5 \mathrm{aA}$ & $10.8 \mathrm{~B}$ & $107 \mathrm{~A}$ \\
\hline & Paper & Large & $18.3 \mathrm{bB}$ & $8.0 \mathrm{aA}$ & $7.0 \mathrm{aA}$ & & $10.1 \mathrm{~A}$ \\
\hline & & Small & $18.0 \mathrm{bA}$ & $9.3 \mathrm{aA}$ & $8.7 \mathrm{aA}$ & & \\
\hline 6 & Polyethylene & Large & $18.7 \mathrm{bA}$ & $8.9 \mathrm{aA}$ & $9.4 \mathrm{aA}$ & & $12.2 \mathrm{~A}$ \\
\hline 6 & & Small & $17.1 \mathrm{bA}$ & $9.0 \mathrm{aA}$ & $9.3 \mathrm{aA}$ & $12.3 \mathrm{C}$ & \\
\hline & Paper & Large & $21.7 \mathrm{bB}$ & $9.3 \mathrm{aA}$ & $8.6 \mathrm{aA}$ & & $12.5 \mathrm{~A}$ \\
\hline & & Small & $13.9 \mathrm{bA}$ & $8.0 \mathrm{aA}$ & $8.0 \mathrm{aA}$ & & \\
\hline 9 & Polyethylene & Large & $17.7 \mathrm{bB}$ & $8.0 \mathrm{aA}$ & $8.7 \mathrm{aA}$ & $105 \mathrm{~B}$ & $10.7 \mathrm{~A}$ \\
\hline & Paner & Small & $15.1 \mathrm{bA}$ & $7.3 \mathrm{aA}$ & $7.2 \mathrm{aA}$ & $10.5 \mathrm{~B}$ & \\
\hline & Paper & Large & $15.6 \mathrm{bA}$ & $9.0 \mathrm{aA}$ & $7.5 \mathrm{aA}$ & & $10.3 \mathrm{~A}$ \\
\hline & & Small & $16.3 \mathrm{bA}$ & $6.7 \mathrm{aA}$ & $6.6 \mathrm{aA}$ & & \\
\hline & Polyethylene & Large & $14.8 \mathrm{bA}$ & $8.0 \mathrm{aA}$ & $7.5 \mathrm{aA}$ & & $10.0 \mathrm{~A}$ \\
\hline 12 & & Small & $14.0 \mathrm{bA}$ & $7.2 \mathrm{aA}$ & $6.7 \mathrm{aA}$ & $9.7 \mathrm{~A}$ & \\
\hline & Paper & Large & $14.3 \mathrm{bA}$ & $7.9 \mathrm{aA}$ & $6.6 \mathrm{aA}$ & & $9.4 \mathrm{~A}$ \\
\hline & & $\mathrm{CV}(\%)$ & & & 15.39 & & \\
\hline & & SME & & 0.745 & & 0.304 & 1.423 \\
\hline
\end{tabular}

*Means followed by the same lowercase letter in the row and the same uppercase letter in the column do not differ statistically from one another by the ScottKnott test $(\mathrm{p}<0.05)$. SME: Standard Mean Error.

Regarding pre-imbibition, pre-soaked seeds formed seedlings with an amount of fresh mass greater than the average. However, considering the dry mass of the shoot, it is possible to verify that the pre-imbibition had no significant influence. This indicates that the difference observed in fresh mass of the shoot has more to do with the existing quantity of water than with a real accumulation of dry mass by the seedlings (Table 4). 
As for the seedlings produced from stored seeds, it was observed that seed size influenced seedling height only after three months of storage and with 12 hours of pre-imbibition, in which case, large seeds formed larger seedlings. Seeds pre-imbibition favored the growth of the seedlings in height, regardless of the period that seeds had remained imbibed (12 or 24 hours). There were no significant differences in seedlings height in relation to pre-imbibition in the large seeds stored for six months, and also in the small ones stored for nine months (Table 5).

The greater height of seedlings obtained from pre-imbibed seeds may have occurred because the germination process starts faster when seeds are pre-soaked in water. As these seeds had germinated first, they had more time to translocate their reserves into the seedling. Seeds stored for six and 12 months formed larger seedlings than those formed from seeds that had been stored for three and nine months (Table 5).

Seed size influenced the collar diameter after six and 12 months of storage, regardless of pre-imbibition; after three months of storage, in seeds that had not pre-imbibed; and after nine months of storage, in seeds that had undergone 12 hours of pre-soaking. In all cases, seedlings formed from large seeds showed a larger collar diameter. Seeds stored for 12 months showed a significant reduction in the diameter of the collar (Table 5).

The number of leaves per seedling was influenced by the size of seed when they were stored for six months. In this condition, large seeds produced seedlings with more leaves. Seeds pre-soaking influenced the number of leaves of seedlings formed from small seeds stored for three months. In this case, seeds soaked for 12 hours had fewer leaves. Small seeds stored for six months and submitted to 24 hours of presoaking showed a better leaf development, whereas the large ones, also stored for six months but without pre-soaking, formed seedlings with the largest number of leaves. As for the storage, only seeds stored for nine months showed a decrease

Table 4. Height $(\mathrm{cm})$, collar diameter $(\mathrm{mm})$, number of leaves, fresh and dry mass ( $\mathrm{g}$ ) of Magonia pubescens seedlings originated from small and large seeds, submitted to different storage times, 30 DAS.

\begin{tabular}{|c|c|c|c|c|c|c|c|c|c|c|c|c|c|c|c|}
\hline \multirow{3}{*}{$\begin{array}{c}\text { Imbibition } \\
\text { (hours) }\end{array}$} & \multicolumn{3}{|c|}{ Height $(\mathrm{cm})$} & \multicolumn{3}{|c|}{ Collar diameter $(\mathrm{mm})$} & \multicolumn{3}{|c|}{ Number of leaves } & \multicolumn{3}{|c|}{ Fresh mass $(\mathrm{g})$} & \multicolumn{3}{|c|}{ Dry mass (g) } \\
\hline & \multicolumn{2}{|c|}{ Size } & \multirow{2}{*}{ Mean } & \multicolumn{2}{|c|}{ Size } & \multirow{2}{*}{ Mean } & \multicolumn{2}{|c|}{ Size } & \multirow{2}{*}{ Mean } & \multicolumn{2}{|c|}{ Size } & \multirow{2}{*}{ Mean } & \multicolumn{2}{|c|}{ Size } & \multirow{2}{*}{ Mean } \\
\hline & Small & Large & & Small & Large & & Small & Large & & Small & Large & & Small & Large & \\
\hline 0 & $10.6 * \mathrm{aA}$ & $11.7 \mathrm{aB}$ & $11.2 \mathrm{~B}$ & $3.2 \mathrm{bA}$ & $3.4 \mathrm{aA}$ & $3.3 \mathrm{~A}$ & $2.7 \mathrm{aB}$ & $2.5 \mathrm{aB}$ & $2.6 \mathrm{C}$ & $2.4 \mathrm{aA}$ & $2.7 \mathrm{aA}$ & $2.6 \mathrm{~B}$ & $0.6 \mathrm{aA}$ & $0.7 \mathrm{aA}$ & $0.6 \mathrm{~A}$ \\
\hline 12 & $12.8 \mathrm{aA}$ & $12.6 \mathrm{aB}$ & $12.7 \mathrm{~B}$ & $3.2 \mathrm{aA}$ & $3.3 \mathrm{aA}$ & $3.2 \mathrm{~A}$ & $3.3 \mathrm{aA}$ & $3.3 \mathrm{aA}$ & $3.3 \mathrm{~B}$ & $2.5 \mathrm{bA}$ & $3.0 \mathrm{aA}$ & $2.8 \mathrm{~A}$ & $0.6 \mathrm{bA}$ & $0.8 \mathrm{aA}$ & $0.7 \mathrm{~A}$ \\
\hline 24 & $15.3 \mathrm{aA}$ & $16.2 \mathrm{aA}$ & $15.7 \mathrm{~A}$ & $3.1 \mathrm{aA}$ & $3.3 \mathrm{aA}$ & $3.2 \mathrm{~A}$ & $3.5 \mathrm{aA}$ & $3.5 \mathrm{aA}$ & $3.5 \mathrm{~A}$ & $2.8 \mathrm{aA}$ & $3.0 \mathrm{aA}$ & $2.9 \mathrm{~A}$ & $0.7 \mathrm{aA}$ & $0.7 \mathrm{aA}$ & $0.7 \mathrm{~A}$ \\
\hline Mean & $12.9 \mathrm{a}$ & $13.5 \mathrm{a}$ & & $3.2 \mathrm{~b}$ & $3.3 \mathrm{a}$ & & $3.1 \mathrm{a}$ & $3.2 \mathrm{a}$ & & $2.6 \mathrm{~b}$ & $2.9 \mathrm{a}$ & & $0.6 \mathrm{~b}$ & $0.7 \mathrm{a}$ & \\
\hline CV (\%) & \multicolumn{2}{|c|}{14.82} & & \multicolumn{2}{|c|}{4.60} & \multicolumn{4}{|c|}{6.62} & \multicolumn{2}{|c|}{11.30} & \multicolumn{4}{|c|}{12.66} \\
\hline SME & \multicolumn{2}{|c|}{0.875} & & \multicolumn{2}{|c|}{0.066} & \multicolumn{4}{|c|}{0.092} & \multicolumn{2}{|c|}{0.138} & \multicolumn{4}{|c|}{0.038} \\
\hline
\end{tabular}

*Means followed by the same lowercase letters in the line and the same uppercase letters in the column do not differ statistically from one another by the ScottKnott test $(\mathrm{p}<0.05)$. SME: Standard Mean Error.

Table 5. Height $(\mathrm{cm})$, collar diameter $(\mathrm{mm})$ and number of leaves of Magonia pubescens seedlings originated from small and large seeds, submitted to different imbibition times after storage.

\begin{tabular}{|c|c|c|c|c|c|c|c|c|c|c|c|c|c|}
\hline \multirow{3}{*}{$\begin{array}{l}\text { Storage } \\
\text { time }\end{array}$} & \multirow{3}{*}{ Seed size } & \multicolumn{4}{|c|}{ Height $(\mathrm{cm})$} & \multicolumn{4}{|c|}{ Collar diameter $(\mathrm{cm})$} & \multicolumn{4}{|c|}{ Number of leaves } \\
\hline & & \multicolumn{3}{|c|}{ Imbibition time } & \multirow{2}{*}{ Mean } & \multicolumn{3}{|c|}{ Imbibition time } & \multirow{2}{*}{ Mean } & \multicolumn{3}{|c|}{ Imbibition time } & \multirow{2}{*}{ Mean } \\
\hline & & 0 & 12 & 24 & & 0 & 12 & 24 & & 0 & 12 & 24 & \\
\hline \multirow{2}{*}{3 Months } & Small & $9.3 * \mathrm{bA}$ & $10.4 \mathrm{aB}$ & $11.1 \mathrm{aA}$ & \multirow{2}{*}{$10.6 \mathrm{~B}$} & $3.0 \mathrm{bB}$ & $3.2 \mathrm{aA}$ & $3.2 \mathrm{aA}$ & \multirow{2}{*}{$3.2 \mathrm{~A}$} & $2.5 \mathrm{aA}$ & $2.4 \mathrm{bA}$ & $2.5 \mathrm{aA}$ & \multirow{2}{*}{$2.5 \mathrm{~A}$} \\
\hline & Large & $9.2 \mathrm{bA}$ & $11.6 \mathrm{aA}$ & $11.9 \mathrm{aA}$ & & $3.2 \mathrm{aA}$ & $3.3 \mathrm{aA}$ & $3.3 \mathrm{aA}$ & & $2.5 \mathrm{aA}$ & $2.6 \mathrm{aA}$ & $2.4 \mathrm{aA}$ & \\
\hline \multirow{2}{*}{6 Months } & Small & $10.3 \mathrm{bA}$ & $11.9 \mathrm{aA}$ & $11.9 \mathrm{aA}$ & \multirow{2}{*}{$11.4 \mathrm{~A}$} & $3.1 \mathrm{aB}$ & $3.2 \mathrm{aB}$ & $3.1 \mathrm{aB}$ & \multirow{2}{*}{$3.2 \mathrm{~A}$} & $2.3 \mathrm{bB}$ & $2.3 \mathrm{bB}$ & $3.3 \mathrm{aB}$ & \multirow{2}{*}{$2.4 \mathrm{~A}$} \\
\hline & Large & $11.3 \mathrm{aA}$ & $11.5 \mathrm{aA}$ & $11.5 \mathrm{aA}$ & & $3.4 \mathrm{aA}$ & $3.3 \mathrm{aA}$ & $3.3 \mathrm{aA}$ & & $2.8 \mathrm{aA}$ & $2.5 \mathrm{bA}$ & $2.4 \mathrm{bA}$ & \\
\hline \multirow{2}{*}{9 Months } & Small & $10.5 \mathrm{aA}$ & $10.9 \mathrm{aA}$ & $10.7 \mathrm{aA}$ & \multirow{2}{*}{$10.8 \mathrm{~B}$} & $3.2 \mathrm{aA}$ & $3.1 \mathrm{aB}$ & $3.2 \mathrm{aA}$ & \multirow{2}{*}{$3.2 \mathrm{~A}$} & $2.3 \mathrm{aA}$ & $2.4 \mathrm{aA}$ & $2.4 \mathrm{aA}$ & \multirow{2}{*}{$2.3 \mathrm{~B}$} \\
\hline & Large & $9.5 \mathrm{bA}$ & $11.4 \mathrm{aA}$ & $11.4 \mathrm{aA}$ & & $3.2 \mathrm{bA}$ & $3.3 \mathrm{aA}$ & $3.1 \mathrm{bA}$ & & $3.3 \mathrm{aA}$ & $2.3 \mathrm{aA}$ & $2.2 \mathrm{aA}$ & \\
\hline \multirow{5}{*}{12 Months } & Small & $9.8 \mathrm{bA}$ & $11.3 \mathrm{aA}$ & $11.2 \mathrm{aA}$ & \multirow{2}{*}{$11.1 \mathrm{~A}$} & $2.9 \mathrm{aB}$ & $2.9 \mathrm{aB}$ & $2.9 \mathrm{aB}$ & \multirow{2}{*}{$3.0 \mathrm{~B}$} & $2.4 \mathrm{aA}$ & $2.5 \mathrm{aA}$ & $2.3 \mathrm{aA}$ & \multirow{2}{*}{$2.5 \mathrm{~A}$} \\
\hline & Large & $9.9 \mathrm{bA}$ & $12.2 \mathrm{aA}$ & $12.2 \mathrm{aA}$ & & $3.1 \mathrm{aA}$ & $3.1 \mathrm{aA}$ & $3.1 \mathrm{aA}$ & & $2.5 \mathrm{aA}$ & $2.6 \mathrm{aA}$ & $2.5 \mathrm{aA}$ & \\
\hline & Mean & $9.9 \mathrm{~b}$ & $11.4 \mathrm{a}$ & $11.5 \mathrm{a}$ & & $3.1 \mathrm{a}$ & $3.2 \mathrm{a}$ & $3.2 \mathrm{a}$ & & $2.4 \mathrm{a}$ & $2.4 \mathrm{a}$ & $2.4 \mathrm{a}$ & \\
\hline & $\mathrm{CV}(\%)$ & \multicolumn{4}{|c|}{11.04} & \multicolumn{4}{|c|}{5.53} & \multicolumn{4}{|c|}{8.56} \\
\hline & SME & \multicolumn{3}{|c|}{0.374} & 0.143 & \multicolumn{3}{|c|}{0.051} & 0.021 & \multicolumn{3}{|c|}{0.065} & 0.026 \\
\hline
\end{tabular}

* Means followed by the same lowercase letters in the row and the same uppercase letters in the column within each storage time do not differ statistically from one another by the Scott-Knott test $(\mathrm{p}<0.05)$. SME: Standard Mean Error. 
in the number of leaves (Table 5).

The size of the seeds did not influence the fresh mass of the seedlings shoots, neither when they were stored for three months in paper bag, nor for nine months in polyethylene bag. On the other treatments, the fresh mass of seedlings shoot from large seeds was greater than that from small ones. Polyethylene packaging jeopardized the accumulation of fresh mass in seedlings shoots formed from large seeds and stored for nine months, and also of those formed by seeds stored for 12 months, regardless of size. Seeds stored for three and 12 months formed seedlings with less fresh shoot mass than those formed from seeds stored for six and nine months (Table 6).

Large seeds produced seedlings with a large quantity of dry mass in the shoot. However, the seeds stored for three months in paper bag and those kept for 12 months in polyethylene

Table 6. Shoot fresh and dry mass (g) of Magonia pubescens seedlings originated from small and large seeds, after storage in different packages.

\begin{tabular}{|c|c|c|c|c|}
\hline \multicolumn{5}{|c|}{ Shoot fresh mass (g) } \\
\hline \multirow{2}{*}{$\begin{array}{l}\text { Storage time } \\
\text { (months) }\end{array}$} & \multirow{2}{*}{ Packaging } & \multicolumn{2}{|c|}{ Seed size } & \multirow{2}{*}{$\begin{array}{c}\text { Mean by } \\
\text { storage }\end{array}$} \\
\hline & & Small & Large & \\
\hline \multirow{2}{*}{3} & Polyethylene & $2.3 * \mathrm{bA}$ & $2.7 \mathrm{aA}$ & \multirow{2}{*}{$2.5 \mathrm{~B}$} \\
\hline & Paper & $2.4 \mathrm{aA}$ & $2.5 \mathrm{aA}$ & \\
\hline \multirow{2}{*}{6} & Polyethylene & $2.4 \mathrm{bA}$ & $2.8 \mathrm{aA}$ & \multirow{2}{*}{$2.7 \mathrm{~A}$} \\
\hline & Paper & $2.5 \mathrm{bA}$ & $3.0 \mathrm{aA}$ & \\
\hline \multirow{2}{*}{9} & Polyethylene & $2.7 \mathrm{aA}$ & $2.6 \mathrm{aB}$ & \multirow{2}{*}{$2.7 \mathrm{~A}$} \\
\hline & Paper & $2.6 \mathrm{bA}$ & $3.2 \mathrm{aA}$ & \\
\hline \multirow{5}{*}{12} & Polyethylene & $2.3 \mathrm{bB}$ & $2.6 \mathrm{aB}$ & \multirow{2}{*}{$2.6 \mathrm{~B}$} \\
\hline & Paper & $2.6 \mathrm{bA}$ & $2.9 \mathrm{aA}$ & \\
\hline & Size mean & $2.5 \mathrm{~b}$ & $2.8 \mathrm{a}$ & \\
\hline & CV (\%) & & 14.0 & \\
\hline & SME & \multicolumn{2}{|c|}{0.093} & 0.043 \\
\hline \multicolumn{5}{|c|}{ Shoot dry mass (g) } \\
\hline \multirow{2}{*}{$\begin{array}{l}\text { Storage time } \\
\text { (months) }\end{array}$} & \multirow{2}{*}{ Packaging } & \multicolumn{2}{|c|}{ Seed size } & \multirow{2}{*}{$\begin{array}{c}\text { Mean by } \\
\text { storage }\end{array}$} \\
\hline & & Small & Large & \\
\hline \multirow{2}{*}{3} & Polyethylene & $0.6 \mathrm{bA}$ & $0.7 \mathrm{aA}$ & \multirow{2}{*}{$0.6 \mathrm{~B}$} \\
\hline & Paper & $0.6 \mathrm{aA}$ & $0.7 \mathrm{aA}$ & \\
\hline \multirow{2}{*}{6} & Polyethylene & $0.6 \mathrm{bA}$ & $0.7 \mathrm{aA}$ & \multirow{2}{*}{$0.7 \mathrm{~B}$} \\
\hline & Paper & $0.6 \mathrm{bA}$ & $0.7 \mathrm{aA}$ & \\
\hline \multirow{2}{*}{9} & Polyethylene & $0.7 \mathrm{aA}$ & $0.6 \mathrm{aB}$ & \multirow{2}{*}{$0.7 \mathrm{~A}$} \\
\hline & Paper & $0.6 \mathrm{bA}$ & $0.8 \mathrm{aA}$ & \\
\hline \multirow{5}{*}{12} & Polyethylene & $0.6 \mathrm{aA}$ & $0.7 \mathrm{aB}$ & \multirow{2}{*}{$0.7 \mathrm{~A}$} \\
\hline & Paper & $0.7 \mathrm{bA}$ & $0.8 \mathrm{aA}$ & \\
\hline & Size mean & $0.6 \mathrm{~b}$ & $0.7 \mathrm{a}$ & \\
\hline & CV $(\%)$ & & 14.28 & \\
\hline & SME & & & 0.012 \\
\hline
\end{tabular}

* Means followed by the same lowercase letters in the line and the same uppercase letters in the column do not differ statistically from one another by the Scott-Knott test $(\mathrm{p}<0.05)$. SME: Standard Mean Error. bag were exceptions, because no significant difference was observed between seed sizes in these cases (Table 6). Generally, large seeds tend to produce individuals of greater vigor. The production of seedlings from larger seeds is a recommendation found in literature (Malavasi and Malavasi, 2001).

Regarding the packaging, a difference in the dry mass of the shoot was observed in seeds stored for nine and 12 months. In these conditions, seeds packed in paper bags produced seedlings with a greater dry mass accumulation in the shoot. Seeds stored for six and 12 months formed seedlings with a larger quantity of dry shoot mass, which indicates that the storage time did not jeopardized the vigor of the seeds (Table 6).

\section{Conclusions}

Seed size did not influence the percentage of germination, but large seeds formed more vigorous seedlings.

The seeds of $M$. pubescens maintained the percentage of germination during the 12 months of storage, despite the decrease observed in the first evaluation after storage and regardless of the packaging used.

Seeds pre-imbibition reduced the mean germination time, which favored the formation of more vigorous seedlings, in comparison to those formed from seeds that were not submitted to imbibition before sowing.

\section{References}

ABUD, H.F.; PEREIRA, D.S.; GONÇALVES, N.R.; PEREIRA, M.S.; BEZERRA, A.M.E. Armazenamento de sementes de xiquexique. Revista Brasileira de Sementes, v.34, n. 3, p.473-479, 2012. http://www.scielo.br/pdf/rbs/v34n3/15.pdf

ARAÚJO, J.R.G.; CERQUEIRA， M.C.M.; GUISCEM， J.M.; MARTINS, M.R.; SANTOS, F.N.; MENDONÇA, M.C.S. Embebição e posição da semente na germinação de clones de porta-enxertos de cajueiro-anão-precoce. Revista Brasileira de Fruticultura, v.31, n.2, p. 552-558, 2009. http://www.scielo.br/pdf/rbf/v31n2/v31n2a33.pdf

ARRUDA, W.; OLIVEIRA, G.M.C.; SILVA, I.G. Toxicidade do extrato etanólico de Magonia pubescens sobre larvas de Aedes aegypti. Revista da Sociedade Brasileira de Medicina Tropical, v.36, n.1, p.17-25, 2003. http://www.scielo.br/pdf/rsbmt/v36n1/15303.pdf

BATISTA, I.M.P.; FIGUEIREDO, A.F.; SILVA, A.M.; SILVA, T.A.F. Efeito de embalagens, ambientes e períodos de armazenamento na germinação e no vigor das sementes de Cedro (Cedrela odorata) em Manaus-AM. Floresta, v.41, n.4, p.809-818, 2011. http://www. scielo.br/pdf/rarv/v39n4/0100-6762-rarv-39-04-0683.pdf

BENEDITO, C.P.; RIBEIRO, M.C.C.; TORRES, S.B.; CAMACHO, R.G.V.; SOARES, A.N.R.; GUIMARÃES, L.M.S. Armazenamento de sementes de catanduva (Piptadenia moniliformis benth.) em diferentes ambientes e embalagens. Revista Brasileira de Sementes, v.33, n.1 p.28-37, 2011. http://www.scielo.br/pdf/rbs/v33n1/03.pdf 
BRASIL. Ministério da Agricultura, Pecuária e Abastecimento. Regras para análise de sementes. Ministério da Agricultura, Pecuária e Abastecimento. Secretaria de Defesa Agropecuária. Brasília: MAPA-ACS, 2009. 395p. http://www.agricultura.gov.br/arq_editor/ file/2946_regras_analise_sementes.pdf

CARVALHO, N.M.; NAKAGAWA, J. Sementes: ciência, tecnologia e produção. 5.ed. Jaboticabal: FUNEP, 2012. 590p.

COELHO, M.F.B.; SANCHES, V.L.; AZEVEDO, R.A.B. Emergência de sementes de timbó em diferentes condições de luz. Revista Caatinga, v.25, n.1, p.194-198, 2012. http://www.redalyc. org/pdf/2371/237123860028.pdf

FERREIRA, D.F. Sisvar: a computer statistical analysis system. Ciência e Agrotecnologia, v.35, n.6, p. 1039-1042, 2010. http:// www.scielo.br/pdf/cagro/v35n6/a01v35n6.pdf

FERREIRA, E.G.B.S.; MATOS, V.P.; FERREIRA, R.L.C.; SALES, A.G.F.A.; SENA, L.H.M. Vigor das sementes de Apeiba tibourbou Aubl. sob difrentes condições de armazenamento e embalagens. Ciência Florestal, v.20, n.2, p.295-305, 2010. https://periodicos. ufsm.br/cienciaflorestal/article/view/1853

GIOTTO, A.C.; MIRANDA, F.S.; MUNHOZ, C.B.R. Aspectos da germinação e crescimento de mudas de Magonia pubescens A. St. Hill. Cerne, v.15, n.1, p.49-57, 2009. http:// repositorio.unb.br/bitstream/10482/15564/1/ARTIGO_ AspectosGermina $\% \mathrm{C} 3 \% \mathrm{~A} 7 \% \mathrm{C} 3 \% \mathrm{~A} 3 \mathrm{oCrescimento} . \mathrm{pdf}$

GRUNENNVALDT, R.L.; CANTARELLI, E.B.; SALAMONI, A.T. Armazenamento e viabilidade de sementes de Cabralea canjerana (Vell.) Mart. Comunicata Scientiae, v.5, n.1, p.98-105, 2014. https:// www.comunicatascientiae.com.br/comunicata/article/view/321

HAIG, D.; WESTOBY, M. Seed size, pollination casts and angiosperm success. Evolutionary Ecology, v. 5, n. 2, p. 231-247, 1991.

LORENZI, H. Árvores brasileiras: manual de identificação e cultivo de plantas arbóreas do Brasil. 5.ed. v.1. Nova Odessa-SP: Plantarum, 2009. 347p.

MACEDO, M.C.; SCALON, S.P.Q.; SARI, A.P.; SCALON FILHO, H.; ROSA, Y.B.C.J.; ROBAINA, A.D. Biometria de frutos e sementes e germinação de Magonia pubescens ST.Hil Sapindaceae. Revista Brasileira de Sementes, v.31, n.2, p.202-211, 2009. http:// www.scielo.br/pdf/rbs/v31n2/v31n2a24.pdf
MAGUIRE, J.D. Speed of germination-aid in selection and evaluation for seedlings emergence and vigor. Crop Science, v.2, n.1, p.176-177, 1962.

MALAVASI, U.C.; MALAVASI, M.M. Influência do tamanho e do peso da semente na germinação e no estabelecimento de espécies de diferentes estágios da sucessão vegetal. Revista Floresta e Ambiente, v.8, n.1, p.211-215, 2001. http:/www.floram.org/files/ v8n\%C3\%BAnico/v8nunicoa27.pdf

MATOS, V.P.; FERREIRA, E.G.B.S.; FERREIRA, R.L.C.; SENA, L.H.M.; SALES, A.G.F.A. Efeito do tipo de embalagem e do ambiente de armazenamento sobre a germinação e o vigor das sementes de Apeiba tibourbou Aubl. Revista Árvore, v.32, n.4, p.617-625, 2008. http://www.scielo.br/pdf/rarv/v32n4/a02v32n4.pdf

POPINIGIS, F. Fisiologia da semente. 2. ed. Brasília: ABRATES, 1985. 298p.

SCALON, S.P.Q.; MUSSURY, R. M.; SALON FILHO, H.; FRANCELINO, C.S.F.; FLORENCIO, D.K.A. Armazenamento e tratamentos pré germinativos em sementes de jacarandá (Jacaranda cuspidifolia Mart.). Revista Árvore, v.30, n.2, p.179-185, 2006. http://www.scielo.br/pdf/rarv/v30n2/a04v30n2.pdf

SILVA, I.G.; GUIMARÃES, V. P.; LIMA, C. G.; SILVA, H. H. G.; ELIAS, C. N.; MADY, C. M.; SILVA, V.V.M.; NERY, A.P.; ROCHA, K.R.; ROCHA, C.; ISAC, E. Efeito larvicida e toxicológico do extrato bruto etanólico da casca do caule de Magonia pubescens sobre Aedes aegypti (Diptera, Culicidae) em criadouros artificiais. Revista de Patologia Tropical, v.32, n.1, p.73-86, 2003. https://www. revistas.ufg.br/iptsp/article/view/4353/3811

SOUZA, F.H.D.; MARCOS-FILHO, J.; NOGUEIRA, M C.S. Características físicas das sementes de Calopogonium mucunoides Desv. associadas à qualidade fisiológica e ao padrão de absorção de água. I. Tamanho. Revista Brasileira de Sementes, v.18, n.1, p.3340, 1996. http://www.bibliotekevirtual.org/revistas/RBS/v18n01/ v18n01a06.pdf

SOUZA FILHO, J. C.; COELHO, M.F.B.; ALBUQUERQUE, M.C.F.E.; AZEVEDO, R.A.B. Emergência de plântulas de Magonia pubescens St. Hil. - Sapindaceae em função da temperatura. Revista Ciências Agrárias, v.54, n.2, p.137-143, 2011. https://ajaes.ufra.edu. br/index.php/ajaes/article/view/316 